\title{
Financial Standing of Polish and Czech Agricultural Cooperatives
}

\author{
Małgorzata MATYJA, Magdalena RAJCHELT-ZUBLEWICZ, Estera PIWONI- \\ KRZESZOWSKA
}

\author{
Wroclaw University of Economics, Wrocław, Poland \\ \{malgorzata.matyja, magdalena.rajchelt, estera.piwoni- \\ krzeszowska\} @ue.wroc.pl
}

\begin{abstract}
Cooperatives are relevant entities of socio-economic country development. In agricultural sector they play a significant role. However, there can be observed clear differences in market position between cooperatives from different countries. The objective of this paper was to investigate the differences in financial standing between Polish and Czech agricultural cooperatives. The analysis consisted of comparison of the following indicators: total assets, fixed assets, total labilities, net profit, total revenues and ROE. The Emis Intelligence Emerging Markets Information Service was used the obtain the data from approximately 200 Polish and 80 Czech agricultural production cooperatives (APCs). The results of the U-Mann-Whitney test confirmed the existence of statistically significant differences between Polish and Czech cooperatives. In considered period (2013-2016), total and fixed assets, total liabilities, net profit, as well as total revenues were higher in Czech cooperatives, while ROE was lower. The findings provoked the authors to formulate five propositions of possible reasons of this phenomenon for further analyses.
\end{abstract}

Keywords: Agricultural Cooperatives, Role of Cooperatives, Cooperatives Business Model, Financial Standing, Profitability.

\section{$1 \quad$ Introduction}

European agricultural cooperatives function as business organizations with a great advantage of direct acting as agents of socio-economic development [16]. They actively help to modernize and improve agricultural activities through the accumulation of goods, offering varied services and increasing the supply and employment rates. They manifest their huge potential for socio-economic structures in rural development by responding to the economic, social, cultural and institutional needs. They are also able to provide mechanisms for organizing and managing of material, financial and human resources. Simultaneously, thanks to the democratic management procedures, cooperatives can respond in a higher degree to the expectations of their members, helping them to increase confidence in the joint action and aspirations. 
Cooperatives play a significant role in the agricultural sector, regardless of the development degree of a country [19]. Notwithstanding, there can be observed clear differences in market position between cooperatives from northern or western Europe and those from CEE countries [5,9]. The first ones represent modern forms of economic activity and expand their structures strengthening the bargaining power of their members $[11,18]$. The second ones are mainly smaller in terms of membership and turnover and, not infrequently, have to face the post-communist impact. Many studies, usually having the character of reports, have described post-soviet cooperatives - their history, current market shares, strengths, the biggest problems and challenges. However, to the best of our knowledge, there has been no analytical treatment of indepth comparisons between these cooperatives.

This paper, by comparing Polish and Czech agricultural cooperatives, develops a financial approach, contributing to filling this gap. Remembering that a cooperative is a dual organization consisting of a cooperative society and a business firm [15], we focus on the latter and provide exemplary financial measures of cooperative's performance evaluation. Against this backdrop the objective of this paper is to investigate the differences in financial standing between Polish and Czech agricultural cooperatives.

\section{The Cooperative Movement in Polish and Czech Agriculture}

\subsection{The Role of Agricultural Cooperatives in Socio-economic Development}

Cooperatives are autonomous associations of people, acting in order to meet their members' needs [12]. Historically, agricultural cooperatives have been the main institutional and organizational tool through which independent farmers were able to withstand the market power held by local and transnational retailers [19]. A number of researchers have investigated their importance in socio-economic development.

Tortia et al. [19] advocate that they "are dramatically important in agriculture". Münkner [12] convinces that cooperatives can be compared to innovators or agents of change in the processes of rural development and poverty reduction. He means that "organized in self-help groups as the losers of rapid change they can improve their own chances to learn how to cope with the challenges of the changing environment" [12]. Further, Münkner claims that cooperatives can also generate new, locally adjusted knowledge. It happens through the knowledge-sharing with external entrepreneurs. He calims that they "experience the positive effects of self-help and group solidarity for improving their own economic and social conditions and for catching up with more advanced competitors by learning from the future" [12].

Melece [10] points out that cooperatives play crucial role in social capital's development. Moreover, she emphasizes that they are recognized as an important instrument for socio-economic improvement of the community. Nembhard [13] agrees by saying that "cooperatives have been found to provide many benefits to communities 
and to have significant positive impact on the economy" [13]. Further, she explains that "many co-operatives create jobs, improve working conditions and provide superior employment benefits. As local businesses, cooperatives increase community economic development and sustainability, and recirculate resources" [13]. Cooperative ownership enhances community relationships (community-business partnerships), wellbeing, leadership development, and women's and youth development.

The argument for scholars is also the emphasis of advantages of cooperatives over the other types of enterprises. For example, Borzaga et al. [4] claim that cooperatives "often achieve economic and social outcomes that are better than those obtained by conventional enterprises and public institutions" [4]. Besides, they are able to coordinate collective action and manage common resources better. It happens by generating, motivating and governing the interaction of their stakeholders in implementing the organizational mission. Moreover, there is quite a lot of evidence that cooperatives survive crises better than other types of business [3]. Cooperative survival rates are longer that conventional small businesses [13]. The long history of cooperative movement can serve as the confirmation of this statement.

\subsection{Agricultural Production Cooperatives in Poland and Czech Republic}

A cooperative is a widely common form of agricultural production in both analyzed countries. Agricultural cooperatives function in all of agricultural sectors, taking the most part in some of them (table 1. based on [2]). For example, cooperatives play a significant role in dairy sector.

Table 1. Cooperative market shares in Czech Republic and Poland in agricultural sectors (\%).

\begin{tabular}{lllllll}
\hline Country & Dairy & Pig meat & Sheep meat & Wine & $\begin{array}{l}\text { Fruit and } \\
\text { vegetables }\end{array}$ & Cereals \\
\hline Czech Republic & 66 & 25 & 20 & 8 & 35 & n/a \\
Poland & 72 & n/a & n/a & 11 & n/a & 7 \\
\hline
\end{tabular}

In post-communist countries, like Poland or Czech Republic, a specific model of agricultural cooperatives still exists. The cooperatives in agriculture under the communist regime denoted agricultural production cooperatives (APCs), in fact collective farms [5]. These cooperatives are the subject of the research in this paper. Initially, after the World War Second, APCs were spontaneously established by the farmers themselves who pooled their land, livestock and equipment in order to farm together for high return achieved via the utilization of economies of scale. Later, they became a tool for collectivization. Despite the forced membership to these cooperatives, the objective of their members was homogenous. However, over the years also land-less people could join the cooperative. This implied mixing two different objectives and the interest of the cooperative became heterogeneous. Nevertheless, in times of command economy, they were an important link throughout the food chains. 
After the collapse of the communist regime, APCs had to face the requirements of the capitalist market. It turned out that to a large extent they met the requirements, because many of them actively work to this day. Currently in Poland, there are more than 700 of APCs with 40000 members [6]. The average size of the cooperative is 350 hectares and the employment rate -60 people. They are situated mainly in the South West and the Northern regions of Poland. Most of them (70\%) specialize in plants growing, producing cereals and industrial oil seeds (30\%). But their business includes also animal husbandry: pig (about 400000 ) and cattle (about 60 000). Some of these cooperatives have multiple activities (services, secondary production, etc).

In Czech Republic APCs are important part of agriculture [2]. Their main function is primary production, providing agricultural commodities and environmental services [6]. They associate mainly land or asset owners and their geographical scope is rather local. The study of Chloupkova [5] shows that Czech APCs are almost 7 times bigger than Polish and have far more shares in total agricultural area. Simultaneously, Chloupkova [5] indicates, that Polish APCs are more productive in than their Czech counterparts and explains this difference as the effect of the different level of collectivization under the communist regime in both countries. However, her findings refer to the period from almost 20 years ago and have not been statistically verified. Therefore it is justified to make an in-depth analysis of comparison Polish and Czech APCs.

\section{Data and Method}

According to the objective of the study described in this article, the basic purpose of its empirical part was to statistically verify whether there are differences in financial standing between the groups of cooperatives operating in Poland and in the Czech Republic. The analysis consisted of comparison of the following indicators: total assets, fixed assets, total labilities, net profit, total revenues and ROE. The choice of these indicators was made to show a relatively wide range of financial situation of compared groups. The assets could serve as evaluation of general wealth of cooperatives, the liabilities - refer to the financing structure, the revenues show the ability to generate income for members and the profit and ROE determine the profitability, although it is not so important in case of cooperatives [4].

The Emis Intelligence Emerging Markets Information Service was used the obtain the data. The analysis was done in STATISTICA program. In order to achieve the research objective, a test of comparisons between groups was used. Because the research populations were significantly different in numbers, it was necessary to use the non-parametric equivalent of Student's $t$ test for independent trials - U-MannWhitney test. While Student's t-test compares the group's averages, the U-MannWhitney test compares the ranking results of a dependent variable [8]. The assumptions of the U-Mann-Whitney test, that the independence of the measurements against each other and that the dependent variables were measured at least on the ordinal scale, were met. The following formula of statistical hypotheses was adopted [17]: null hypothesis $\mathrm{H} 0$ : the averages in the groups are the same, alternative hypothesis $\mathrm{H} 1$ : at least two 
averages differ between each other. The verification of hypotheses consisted in rejection of the null hypothesis in favor of accepting and adopting its alternative, while maintaining the significance level $\alpha=0,05$. Rejection of the null hypothesis would indicate the existence of statistically significant differences between the compared populations. The static results were supplemented with a graphic presentation using a box and whisker plots.

\section{$4 \quad$ Research Results}

The studies concerned on the comparison of the situation of Polish agricultural cooperatives and their Czech counterparts. Due to formal reasons, all operating entities could not be qualified for the study, which is why the authors used the following filters: Sector: Poland - according to the NAICS Classification - main areas of activity: Agricultural Crops, Animal Production and Aquaculture; Czech Republic: according to the CZ-NACE Classification - Crop and Animal Production, Hunting and Related Service Activities; Status: run an economic activity. The time range of the analysis covered the period of 2013-2016. Fig. 1 shows that in the sample there were much more Polish than Czech cooperatives, but in the case of the latter ones their number was growing, while the other ones - it was decreasing.

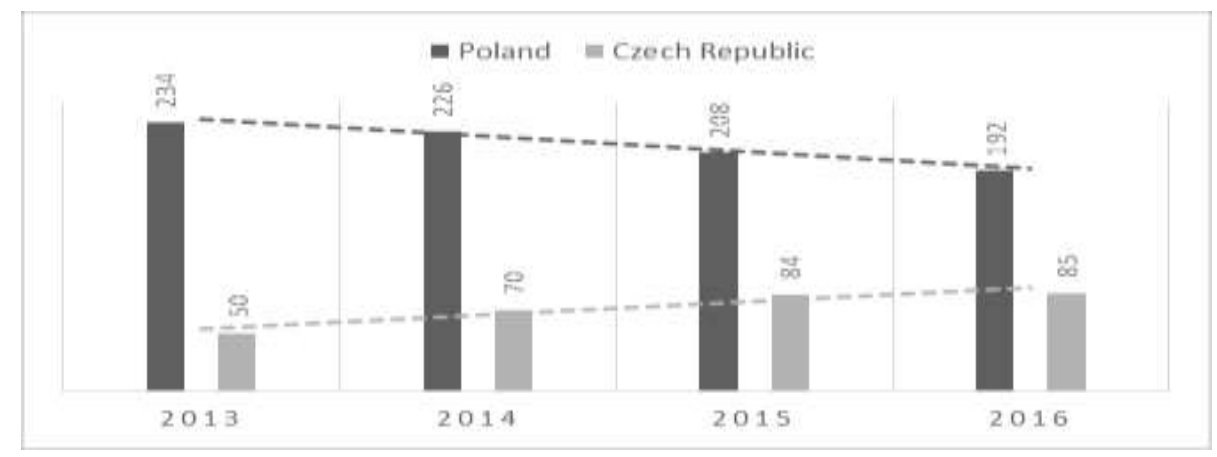

Fig. 1. Number of cooperatives in the sample in Poland and the Czech Republic in 2013-2016.

The analysis of differences between cooperatives in Poland and the Czech Republic in 2013, starts a comparison between the average in the analysis range of indicators (Fig. 2). This comparison shows that Czech cooperatives achieve better average financial results. Only in the scope of ROE Polish cooperatives lead the way. 

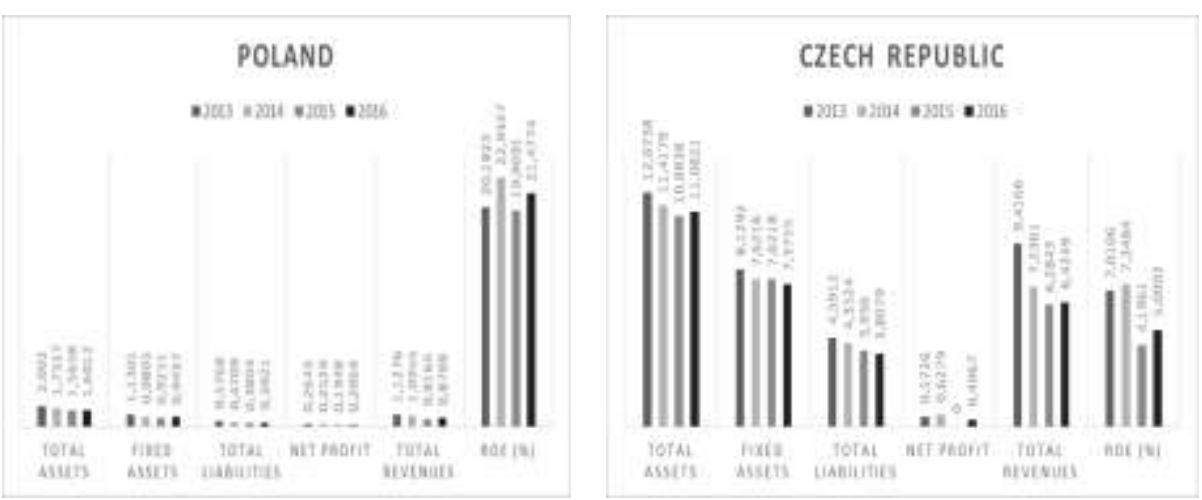

Fig. 2. The average results in the area of analyzed indicators in Polish and Czech cooperatives.

In order to have a full picture of the situation, it is worth to also look at the box and whisker plots prepared in terms of the medians for each indicator (Fig. 3). The frame whisker-charts prepared for subsequent years taken for analysis, also served to elaborate a summary of the present research, however, due to the limited volume of publication, only the charts for 2013 were included in the article. 

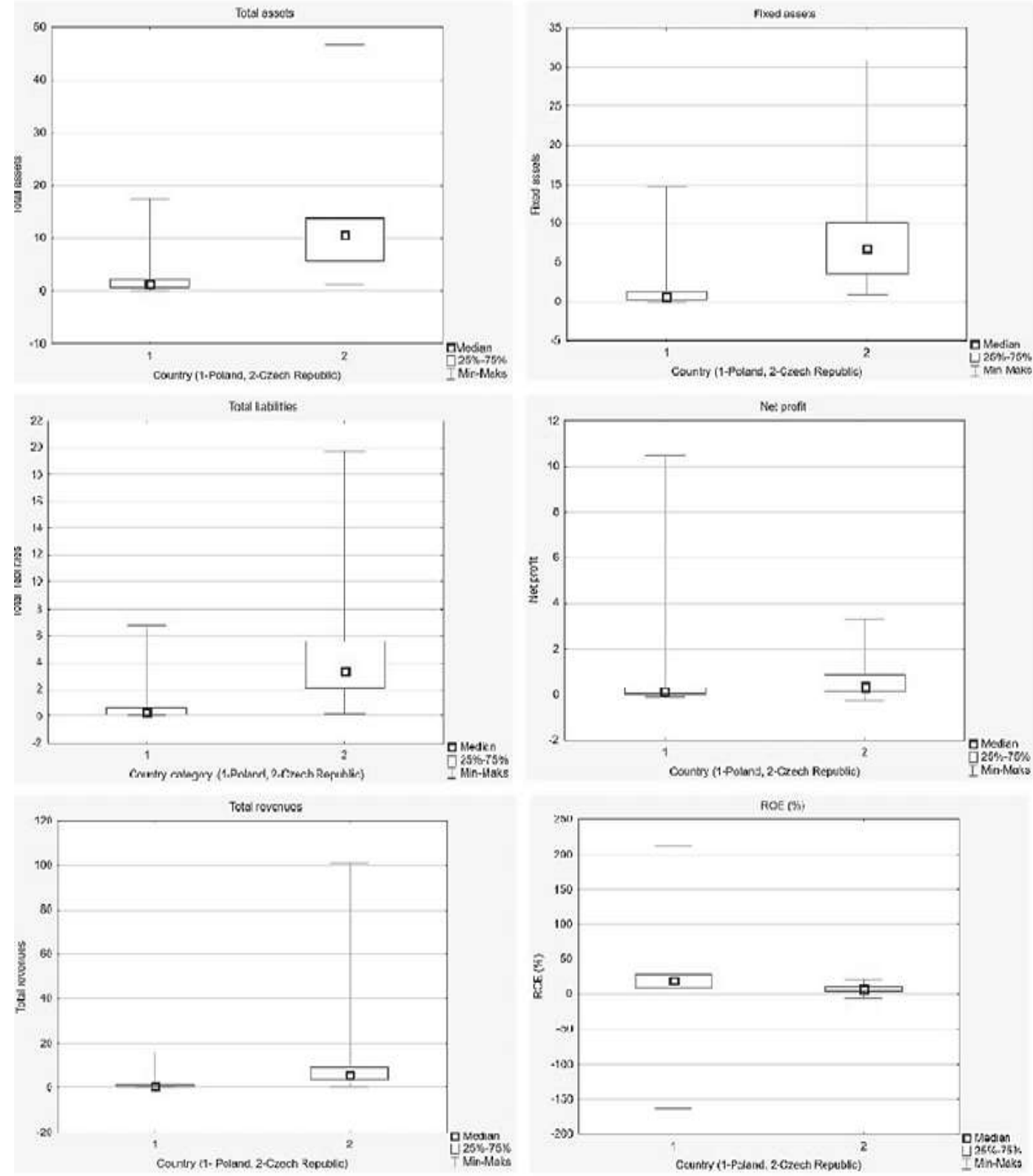

Fig. 3. The frame-whisker charts for all analyzed indicators in 2013.

The results of the U-Mann-Whitney test confirm the existence of statistically significant differences between Polish and Czech cooperatives (table 2). In considered period, total and fixed assets, total liabilities, net profit, as well as total revenues are higher in Czech cooperatives, while ROE (\%) is lower. 
Table 2. The results of the U-Mann-Whitney test with the p-values and the medians of Polish cooperatives in the comparison to their Czech counterparts

\begin{tabular}{|c|c|c|c|c|c|c|c|c|}
\hline & $\begin{array}{l}\text { p-value } \\
2013\end{array}$ & $\begin{array}{l}\text { median } \\
2013\end{array}$ & $\begin{array}{l}\text { p-value } \\
2014\end{array}$ & $\begin{array}{l}\text { median } \\
2014\end{array}$ & $\begin{array}{l}\text { p-value } \\
2015\end{array}$ & $\begin{array}{l}\text { median } \\
2015\end{array}$ & $\begin{array}{l}\text { p-value } \\
2016\end{array}$ & $\begin{array}{l}\text { median } \\
2016\end{array}$ \\
\hline Total assets & 0.000000 & higher & 0.000000 & higher & 0.000000 & higher & 0.000000 & higher \\
\hline Fixed assets & 0.000000 & higher & 0.000000 & higher & 0.000000 & higher & 0.000000 & higher \\
\hline $\begin{array}{l}\text { Total } \\
\text { labilities }\end{array}$ & 0.000000 & higher & 0.000000 & higher & 0.000000 & higher & 0.000000 & higher \\
\hline Net profit & 0.000003 & higher & 0.000000 & higher & 0.000297 & higher & 0.000004 & higher \\
\hline $\begin{array}{l}\text { Total } \\
\text { revenues }\end{array}$ & 0.000000 & higher & 0.000000 & higher & 0.000000 & higher & 0.000000 & higher \\
\hline ROE (\%) & 0.000000 & lower & 0.000000 & lower & 0.000000 & lower & 0.000000 & lower \\
\hline
\end{tabular}

The results presented in the table show that agricultural cooperatives functioning in Poland and their Czech counterparts, statistically differentiate them in terms of all indicators taken into consideration in the study. Thus, it could be concluded that Polish and Czech cooperatives differ significantly in terms of financial results.

\section{$5 \quad$ Discussion and Conclusion}

Czech and Polish agricultural cooperatives have a similar business history. They operate in similar climatic and natural conditions, which is important when we think of their agricultural profile.

Furthermore, they operate on similar markets that are regulated by the same EU requirements. However, despite these similarities, they have different financial standings. This contradiction provokes to look for the reasons of those differences.

First, Czech cooperatives are larger in terms of the members numbers [5]. In turn, this may be the cause of adopting different business models. In Poland the members of agricultural cooperatives work together on one farm - a cooperative. Czech cooperatives associate individual farms that trade with their cooperatives but don't work together. Yet, there is no in-depth research on relations between the business model and the bargaining power and financial standing of Czech and Polish agricultural cooperatives. Consequently, taking into account the considerations about the impact of the agricultural cooperatives business model on their bargaining power and financial standing the following propositions could be formulated:

Proposition 1: there is a relationship between the business models of agricultural cooperatives and their bargaining power;

Proposition 2: there is a relationship between the business models of agricultural cooperatives and their financial standings. 
Second, despite the fact that Czech and Polish agricultural cooperatives both have a post-communist business history, they were and still are developed in different national cultures. These national cultures can be the basis for different approaches to cooperative actions. Consequently, the following proposition might be formulated:

Proposition 3: the culture of cooperatives affects the business model of agricultural cooperatives.

The last but not least cause of the financial standings differences between Polish and Czech agricultural cooperatives may be the differences in the management of these entities. From this point of view, there emerges a large research field. Research can be carried out both on the organizational and micro fundamental levels. Consequently, the following proposition might be formulated:

Proposition 4: the organizational and micro fundamental management differences cause the financial standing differences of Czech and Polish agricultural cooperatives.

Moreover, it should be considered whether the indicators such as total and fixed assets, total liabilities, net profit, total revenues and ROE are appropriate and sufficient for evaluating the financial standing of Czech and Polish agricultural cooperatives. The evaluation of cooperatives performance is more difficult than in the case of investorowned enterprises [14], because "cooperatives are autonomous associations of persons, designed to meet their members' needs" [12] and for this reason "cooperatives have the tendency to use more debt than IOFs" [14]. Thus, this not-for-profit oriented business gives agricultural cooperatives members higher, satisfying prices for supplied products, thereby decreasing the total profit [9]. Other features of the financial structure of cooperatives are as follows:

- "most of the cooperative's share capital has to be held by the members who take part in its economic activity,

- shareholding does not determine the member's rights in the cooperative,

- any return on paid-up capital must be at a limited rate,

- part of the cooperative's reserves is indivisible and cannot be distributed to the members" [7].

Therefore, taking into account the financial structure of cooperatives it is right to accept that "most of the commonly used financial measures give an incomplete picture of a cooperative's performance" [1]. Consequently, the following proposition might be formulated:

Proposition 5: in the evaluation of the agricultural cooperatives' financial standings, profit indexes per member might be calculated apart from typical profitability ratios.

Cooperatives have been operating on the market of many European countries for many years. Although many researchers are interested in these types of enterprises, there are still research gaps. Filling these gaps is not only cognitively interesting, but it is also important from the community point of view because cooperatives are relevant entities of socio-economic country development. 


\section{References}

1. Betts Liebrand, C.: Measuring the Performance of Agricultural Cooperatives. USDA Rural Development Research Report 213, Washington (2007).

2. Bijman, J., Iliopoulos, C., Poppe, K., Gijselinckx, C., Hagedorn, K., Hanisch, M., Hendrikse, G.W.J., Kuhl, R., Ollila, P., Pyykkonen, P., Sangen, G.: Support for Farmer's Cooperatives. EC, Brussels (2012).

3. Birchall, J.: The potential of co-operatives during the current recession; theorizing comparative advantage. Journal of Entrepreneurial and Organizational Diversity 2(1), 1-22 (2013), DOI: 10.5947/jeod.2013.001.

4. Borzaga, C., Depedri, S., Tortia, E.: The Role of Cooperative and Social Enterprises: a Multifaceted Approach for an Economic Pluralism. Euricse Working Papers, vol. 09 (2009), DOI: $10.2139 / \mathrm{ssrn} .1622143$.

5. Chloupkova, J.: European Cooperative Movement: Background and Common Denominators. Royal Veterinary and Agricultural University, Copenhagen (2003).

6. Copa-Cogeca: Development of Agricultural Cooperatives in the EU 2014, http://zadruge.coop/upload_data/site_files/development-of-agricultural-cooperatives-inthe-eu_2014.pdf, last accessed 2018/11/18.

7. Garcia, G. F.: Cooperative Finance and Cooperative Identity. Euricse Working Paper, vol. 45 (2012).

8. Mann, H. B., Whitney, D. R.: On a Test of Whether One of Two Random Variables is Stochastically Larger than the Other. The Annals of Mathematical Statistics 18(1), 50-60 (1947), DOI: 10.1214/aoms/1177730491.

9. Matyja, M.: Profitability of Agricultural Cooperatives. Selected Methodical Aspects of Measurement and Analysis. Journal of Agribusiness and Rural Developement 3(49), 279286 (2018), DOI: 10.17306/J.JARD.2018.00417

10. Melece, L.: Agricultural Cooperatives for Social Capital Development in Latvia. Organizaciju Vadyba: Sisteminiai Tyrimai 66, 53-67 (2013), DOI: 10.7220/MOSR.1392.1142.2013.66.4.

11. Mierzwa, D.: Przedsiębiorstwo spółdzielcze - dotychczasowe doświadczenia i kierunki rozwoju. Roczniki Nauk Rolniczych, Seria G 96(3), 293-301 (2009).

12. Münkner, H-H.: Co-operation as a Remedy in Times of Crisis. Agricultural Co-operatives in the World. Their Roles for Rural Development and Poverty Reduction. Marburg Studies on Cooperation and Cooperatives, vol. 58 (2012).

13. Nembhard, J. G.: Understanding and Measuring the Benefits and Impacts of Co-operatives. In: Brown, L., Carini, Ch., Nembhard, J. G, Ketilson, L. H., Hicks, E., McNamara, J., Novkovic, S., Rixon, G., Simmons, R. (eds.) Co-Operatives for Sustainable Communities. Tools to Measure Co-operative Impact and Performance, pp. 152-179. Friesens Corporation, Altona (2015).

14. Nilsson, J., Dijk, G. van: Strategies and Structures in the Agro-Food Industries. Van Gorcum \& Comp. B.V., Assen (1997).

15. Nilsson, J., Hendrikse, G.: Gemeinschaft and Gesellschaft in Cooperatives. In: Tuunanen, M., Windsperger, J., Cliquet, G., Hendrikse, G. (eds.) New Developments in the Theory of Networks, pp. 339-352. Springer-Verlag, Berlin Heidelberg (2011), DOI 10.1007/978-37908-2615-9_19.

16. Popescu, G.: Cooperative Phenomenon in European Context. Personal RePEc Archive, Munich (2014).

17. Stanisz, A.: Przystępny kurs statystyki z zastosowaniem STATISTICA PL na przykładach z medycyny, T. 1., Statsoft Polska, Kraków (2006). 
18. Suchoń, A.: Spółdzielnie w rolnictwie w wybranych Państwach Europy Zachodniej; aspekty prawne i ekonomiczne. Zeszyty Naukowe Szkoły Głównej Gospodarstwa Wiejskiego w Warszawie, Seria Problemy Rolnictwa Światowego 12(2), 94-103 (2012).

19. Tortia, E., Valentinov, V., Iliopoulos, C.: Agricultural Cooperatives. Journal of Entrepreneurial and Organizational Diversity 2(1), 23-36 (2013), DOI: 10.5947/jeod.2013.0002. 